\title{
O projeto de desconstrução do cristianismo de Jean-Luc Nancy
}

The project of Deconstruction of Christianity by Jean-Luc Nancy

\author{
Etienne Alfred Higuet*
}

\begin{abstract}
Resumo
Pretendemos percorrer, com Jean-Luc Nancy, os principais momentos do processo de construção e desconstrução do cristianismo e do Ocidente, até o seu estado presente, consequência da "morte de Deus" como própria destinação do cristianismo. A desconstrução do cristianismo e, pela mesma ocasião, do Ocidente que se identifica com ele, objetiva reduzi-lo à essência do seu fenômeno. Tratase do "desenclausuramento" ou da "declosão" recíproca das heranças da religião e da filosofia. Ao longo da história, por um movimento virtualmente infinito, a fé cristã se descobre remetendo a um momento anterior a ela mesma, momento que ela constantemente renova e clareia. Uma das principais tarefas é a desconstrução do monoteísmo. Com a figura de Cristo, a renúncia ao poder divino e à sua presença torna-se o próprio ato de Deus. A ausência ou o vazio-de-divindade é sua verdade mais profunda. Mostraremos, também, algumas implicações éticas e políticas do processo. Concluiremos com algumas reflexões críticas a respeito do método adotado pelo autor e dos principais resultados do percurso.
\end{abstract}

Palavras-chave: Jean-Luc Nancy; desconstrução; cristianismo; monoteísmo; sentido.

\begin{abstract}
We intend to survey, with Jean-Luc Nancy, the key moments of the process of construction and deconstruction of Christianity and the West, until its present state as a result of the "death of God" as own destiny of Christianity. The deconstruction of Christianity and, at the same time, the West who identifies with it, aims to reduce it to the essence of its phenomenon. This is the reciprocal "unclosion" or opening of the inheritances of religion and philosophy. Throughout history, by a virtually infinite movement, the Christian faith find out itself referring to an earlier time to itself, that it constantly renews and brightens. One of the main tasks is the deconstruction of monotheism. With the figure of Christ, the waiving of divine power and its presence becomes the very act of God. The absence or the empty-of-divinity is its deepest truth. We will show too some political and ethical implications of the process. We conclude with some thoughts about criticism of the method adopted by the author and the main results of the survey.
\end{abstract}

Keywords: Jean-Luc Nancy, deconstruction, Christianity, monotheism, meaning.

Artigo recebido em 22 de janeiro de 2016 e aprovado em 21 de junho de 2016.

* Doutor em Teologia pela Université Catholique de Louvain (1978). Atualmente é professor visitante da Universidade do Estado do Pará. País de origem: Bélgica. E-mail: ethiguet@uol.com.br

Horizonte, Belo Horizonte, v. 14, n. 42, p. 518-542, abr./jun. 2016 - ISSN 2175-5841 


\section{Introdução}

Da Antiguidade à modernidade, o destino do Ocidente está atrelado à história do cristianismo, em estado de permanente construção e desconstrução. A desconstrução do cristianismo e, pela mesma ocasião, do Ocidente que se identifica com ele, tem como objetivo: reduzi-lo à essência do seu fenômeno. Heidegger entendia a desconstrução (Destruktion ou Abbau) como a ação de desmontar, desajuntar, "dar uma folga" à junção das peças, para reabrir a possibilidade - o vazio - de onde procede o ajuntamento, possibilidade que ele mesmo oculta. O gesto de desconstrução - talvez só possível no interior do cristianismo - é o gesto de uma abertura e de uma reabertura, de um desenclausuramento, em direção ao que deve ter antecedido toda construção, tanto do cristianismo quanto do Ocidente. Trata-se do desenclausuramento recíproco das heranças da religião e da filosofia, da reabertura da clausura da metafísica ou da onto-teologia, ou ainda da totalidade que se acha realizada na sua auto-referência. Ao longo da história, por um movimento virtualmente infinito, a fé cristã se descobre remetendo àquilo que a antecede, ao que ela renova e clareia.

Graças à historicidade do conteúdo mesmo da fé, o cristianismo perde cada vez mais o caráter de uma religião, sendo a "religião da saída da religião" (Marcel Gauchet). É que, com a figura de Cristo, a renúncia ao poder divino e à sua presença torna-se o próprio ato de Deus. ${ }^{1}$ A ausência ou o vazio-de-divindade é sua verdade mais profunda. Por isso, não se trata de salvar ou ressuscitar a religião, menos ainda de voltar para ela, o que poderia piorar o seu estado já crítico e aumentar os perigos que ela faz correr à humanidade, no que toca ao pensamento, ao direito, à liberdade e à dignidade humana. Trata-se, ao contrário, de abrir a

\footnotetext{
${ }^{1}$ Este trabalho analisará o projeto de desconstrução do cristianismo apresentado em dois livros de Jean-Luc Nancy: La déclosion (Déconstruction du christianisme, I), publicado em 2005; e L'adoration (Déconstruction du christianisme, II), de 2010. Com alguns complementos em outras obras indicadas na bibliografia. Deve-se observar de início que haverá desconstrução de pressupostos da teologia cristã, que não seriam, em princípio, condizentes com a proposta filosófica de Jean-Luc Nancy, ou, melhor, o nosso autor observa os pressupostos se desconstruírem a si mesmos ao longo da história do Ocidente. Nancy opera uma descrição filosófica desconstrutiva da teologia, uma retomada do discurso religioso confessional no seio de uma a-teologia filosófica ateia, que modifica fundamentalmente o sentido do discurso teológico. Assim, a quénose de Deus desemboca na ausência definitiva de Deus, e não é um momento que levaria à reconstrução da presença divina na exaltação do Filho, como no hino da Carta aos Filipenses.
}

Horizonte, Belo Horizonte, v. 14, n. 42, p. 518-542, abr./jun. 2016 - ISSN 2175-5841 
simples razão (filosófica) à ilimitação que constitui a sua verdade. A religião, enquanto garantia de uma preservação providencial do mundo e da existência e, com ela, o humanismo que ela produziu, perdeu, junto com sua legitimidade, o sentido da sua própria força: a vitalidade do ato de fé deixou lugar ao controle dogmático e institucional, enquanto a abertura do mundo à própria exterioridade não a um além-mundo, paraíso ou inferno - ficou reduzida a uma gestão interessada do mundo. O pensamento está diante da tarefa de reassumir esta abertura, de abrir a racionalidade à dimensão própria do absoluto, de dar lugar conforme as palavras de Kant - a uma fé da razão.

A civilização da "morte de Deus" ou do niilismo deixou de responsabilizar-se pelo vazio aberto na sua raiz e está deixando espaço para formas piores de exaltação messiânica, mística e profética. As condições estão dadas para um delírio incendiário que vai se propagar sem resistência no deserto do sentido e verdade que fizemos ou deixamos crescer. Está faltando à convivência humana uma dimensão ontológica do "ser-juntos", articulada na "excedência" absoluta de sentido e de paixão pelo sentido outrora designado pela palavra "sagrado". O sentido do mundo que vinha de fora do mundo deixou de existir.

Ora, desde Nietzsche, Heidegger e Wittgenstein, abriu-se, de diversas formas, um "exterior do mundo" em plena imanência mundana, deixando para a razão a exigência de iluminar a própria obscuridade ou, melhor, de deixar o obscuro emitir a própria claridade. Já chegou o tempo de um “desenclausuramento", de uma “declosão" mútua da religião e da filosofia. É hora de abrir a clausura pela qual a metafísica se trancou, com a chancela do cristianismo e do monoteísmo. Na clausura metafísica, a totalidade do ente se representa como presença fundada, além do mundo, na Ideia ou Ens Summum, Sujeito ou Vontade. Mas o movimento de desestabilização do ente em totalidade, reconhecido por Nietzsche e Heidegger, é produto da própria metafísica. Esta desconstrói-se constitutivamente e, assim, desenclausura em si mesma a presença e a certeza do mundo fundado em razão, num processo que acompanha toda a 
história da filosofia. Poderíamos falar, aqui, em desconstrução da onto-(a)-teologia.

A razão, quando passou a falar de coisas sérias: a morte, o mundo, o serjuntos, o ser-em-si-mesmo, a verdade, introduziu o alogon - o que não pode ser dito, ser objeto de logos, o que é inacessível - enquanto dimensão extrema, excessiva e necessária do logos. A metamorfose da relação geral ao mundo, que surge a partir do momento em que o inacessível enquanto tal assume forma e função no pensamento, no saber e na conduta (no cristianismo), foi decisiva para a formação do Ocidente. Ao assumir de modo mais radical e mais explícito o desafio do alogon , o cristianismo suscita, a partir do coração da clausura onde se situa, e na sua excedência, o movimento de uma desconstrução, de um "desajuntamento" das pedras do edifício e de um olhar para o vazio, para a "coisa-nada”. É que o cristianismo designa essencialmente a exigência de abrir neste mundo uma alteridade ou uma alienação incondicional, indicando assim o alcance infinito, de direito, do próprio movimento de desconstrução e desenclausuramento. Essa exterioridade do mundo não existe, mas define e mobiliza a ex-sistência: a abertura do mundo à alteridade inacessível. O cristianismo desenclausura, no seu gesto essencial, a clausura que ele mesmo constrói, quando empresta à metafísica da presença o seu mais forte recurso imaginário. Já que não há nenhum termo indesconstrutível, o desenclausuramento nunca termina de abrir o que ele abre: o Ocidente, a metafísica, o saber, o si-mesmo, a forma, o sentido, a própria religião (NANCY, 2005, p. 9-25).

Esboçaremos primeiro, com Jean-Luc Nancy², a descrição do processo de construção e desconstrução do cristianismo e do Ocidente, até o seu estado

\footnotetext{
2Jean-Luc Nancy, filósofo francês, nasceu em Bordeaux em 1940. 0 meio cristão impregna seus anos de formação: a Juventude Católica, em primeiro lugar, e depois os ensinamentos do jesuíta Georges Morel, especialista de Hegel. Durante os estudos de filosofia na Sorbonne, é aluno de Georges Canguilhem e Paul Ricoeur e descobre Heidegger. Ao desistir de estudos de teologia, descobre o estruturalismo e encontra Jacques Derrida, Louis Althusser e Gilles Deleuze. Desde 1968, é professor de filosofia na Universidade de Estrasburgo, onde se dedica, junto com o colega e amigo Philippe Lacoue-Labarthe, a um trabalho de "desconstrução" das artes, especialmente da literatura, e do político, influenciado por Georges Bataille e Maurice Blanchot. A partir dos anos oitenta, volta às questões essenciais da filosofia, como finitude e infinito na existência humana. Com La déclosion (2005) e L'adoration (2010), o filósofo volta às fontes do cristianismo, para detectar a clausura que ainda precisa ser desconstruída, liberar todos os seus recursos para transcender o seu sentido, esgotar a sua essência. O livro L'intrus (2000) conta na primeira pessoa o transplante de coração que permitiu ao homem adiar a morte anunciada. Jean-Luc Nancy manifesta também preocupações pedagógicas, através de artigos de divulgação e de crônicas nas ondas de France Culture (CAHEN, 2012).
}

Horizonte, Belo Horizonte, v. 14, n. 42, p. 518-542, abr./jun. 2016 - ISSN 2175-5841 
presente, consequência da "morte de Deus" como própria destinação do cristianismo. Em seguida, dedicaremos a maior parte do ensaio ao processo de desconstrução do teísmo (monoteísmo) e do ateísmo. Procuraremos mostrar também as implicações éticas e políticas do processo. Concluiremos com a discussão de alguns pontos sensíveis detectados no pensamento do autor.

\section{A desconstrução do cristianismo³}

Em perspectiva fenomenológica, o cristão ou o cristianismo é a própria coisa (die Sache selbst) que deve ser pensada. Antes de iniciar a análise, precisamos colocar duas diretrizes: só pode ser atual um cristianismo que contempla a possibilidade presente da sua negação; só pode ser atual um ateísmo que contempla a realidade da sua procedência cristã.

O autor parte da questão do caráter indissociável, até hoje, de toda a tradição ocidental e do cristianismo. Apesar do encobrimento sistematicamente operado pela filosofia, a massiva referência cristã configura e constitui, como seu eixo, toda a nossa tradição, inclusive a nossa referência ao que veio antes do cristianismo. O cristianismo pertence indissoluvelmente ao Ocidente enquanto processo de auto-encolhimento e auto-superação. Desenvolveu, ao mesmo tempo, uma afirmação de poder, dominação e exploração teológico-econômico-política e uma afirmação inversa de despojamento, abandono-de-si e auto-esvaziamento. Apesar da descristianização, as nervuras do cristianismo continuam condicionando todo o pensamento ocidental.

Embora esteja ainda vivo, o cristianismo deixou de oferecer um sentido para a vida, enquanto estrutura organizadora de uma experiência coletiva. Está sofrendo o processo chamado de "fim das ideologias", isto é, fim do sentido prometido ou fim da promessa do sentido como visada, fim e realização. Daí a necessidade da sua desconstrução. Mas a nervura do sentido enquanto encerrado, por ter chegado ao

${ }^{3}$ Ver especialmente o capítulo: "La déconstruction du christianisme", in: NANCY, 2005, p. 203-231. 
limite da sua própria possibilidade, continua sendo a nervura central da “ocidentalidade”. O mundo moderno não representa um desvio em relação à referência cristã, pois ele mesmo constitui o devir do cristianismo, edificando-se na base de uma denegação interna da sua referência cristã. Ele é, ao mesmo tempo, denegação e recondução plena e inteira desta referência.

A desconstrução deverá tentar alcançar o coração do movimento de distensão, abertura e dissolução, que constitui a essência do cristianismo. Trata-se de percorrer novamente a história do cristianismo como surgimento absoluto (no dia de Natal!) e como integração lenta da herança anterior: judaísmo, helenismo, romanidade. Nancy indica três etapas principais na formação do cristianismo: um cristianismo judeu, um cristianismo grego e um cristianismo romano. Juntos, eles correspondem à constituição de uma integridade dogmático-eclesial e à tensão interna de uma identidade que só se concebe através da sua relação com o que ela nega ao superá-lo. Contudo, Nancy não se dá ao trabalho de refazer esse percurso. Aliás, ele reconhece que os seus ensaios constituem apenas alguns elementos de um canteiro de obras a céu aberto. A história do cristianismo, à luz do plano salvífico de Deus, identifica-se com a história humana universal, a qual se torna uma história fundamentalmente cristã.

Há, no cristianismo, uma tensão constitutiva entre a passagem e a presença, entre a antecedência virtualmente infinita e um futuro igualmente infinito. Essa tensão é precisamente o que se chama o sentido. Como dimensão do sentido, o cristianismo é, ao mesmo tempo, a abertura do sentido e o sentido como abertura. A tensão chega ao paroxismo quando o absoluto da presença (parusia) se confunde com a infinidade da passagem: lá onde o sentido se encerra, se esgota, se realiza, não há mais sentido. Assim, a "morte de Deus"4 enuncia a própria destinação do

\footnotetext{
4 "A morte de Deus é o pensamento final da filosofia, que o propõe assim como fim à religião: é o pensamento para o qual o Ocidente nunca deixou de tender. Ela significa: a morte da morte, negação da negação, o fim da separação de Deus, a divinização do homem, a absolutização de seu saber e de sua história (ou a afirmação da sua total insignificância) e a dor infinita que é o destino do seu trabalho, do seu discurso, da sua morte, quando eles têm como objetivo e como sentido a reconciliação infinita. [...] Em certo sentido, todas as nossas grandes religiões são inseparáveis da filosofia: isto é, do fim - do objetivo e da suspensão - onto-teo-lógica da religião" (NANCY, 1997, p. 23).
}

Horizonte, Belo Horizonte, v. 14, n. 42, p. 518-542, abr./jun. 2016 - ISSN 2175-5841 
cristianismo, que se realiza como niilismo. Este é apenas a incandescência final do sentido, o sentido no seu excesso. Afinal, nada é revelado, senão o fim da própria revelação. O revelado é que Deus é o revelável, o Aberto enquanto tal. Pensar a infinidade do sentido equivale a pensar o sentido como abertura absoluta ao próprio sentido, até alcançar um sentido vazio de todo conteúdo, de toda figura e determinação. Convém tentar a desconstrução do cristianismo nesse ponto em que o cristianismo se constitui e simultaneamente se desfaz.

Desde a origem, o cristianismo afirma e nega, ao mesmo tempo, a desconstrução, ao colocar, no lugar da estrutura da origem, o anúncio (euaggelion) do fim. No seu núcleo, o evangelho não é nem previsão nem promessa, mas apenas anúncio sem conteúdo. A estrutura fundamental do anúncio e da abertura do sentido se concretiza no desenvolvimento dogmático e teológico. Assim, ao desmontar ou desconstruir os constituintes filosóficos do dogma e da teologia, chegaremos ao conjunto das nervuras filosóficas do nosso pensamento (ocidental). A cristologia é o coração da teologia cristã. Por sua vez, a doutrina da encarnação é o coração da cristologia e, no centro dessa doutrina, encontramos a doutrina da homoousia, da consubstancialidade, da identidade ou comunidade de ser e de substância entre o Pai e o Filho. O dogma da encarnação mobiliza as ideias de "natureza" ou "essência" e de "hipóstase" ou "apresentação sensível", para estabelecer que a pessoa de Jesus é identicamente a pessoa de um homem e a pessoa de Deus numa única manifestação (Cf. NANCY, 2005, p. 58). A parusia (presença) da homoousia representa a abertura infinita do sentido da ousia pensada como presença, parusia de si mesma. A partir da ousia, podemos resgatar o conjunto da corrente filosófica dos conceitos da ontologia, até a questão heideggeriana da diferença óntico-ontológica e do sentido do ser, sobre o pano de fundo da própria abertura (Cf. NANCY, 2005, p. 219).

Verbum caro factum est (o verbo foi feito carne) ou logos sarx egéneto (o logos tornou-se carne), no prólogo do Evangelho de João, é a fórmula da “encarnação”, pela qual Deus se faz homem. A humanidade de Deus é, ao mesmo 
tempo, o traço decisivo do cristianismo e um traço determinante de toda a cultura ocidental, até no coração do seu "humanismo". A expressão significa que o verbo não precisou penetrar numa carne antes dada fora dele: o próprio verbo tornou-se a carne. Pela sua natureza trinitária, o espírito divino cristão já está fora de si mesmo - assim como o deus dos três monoteísmos já é essencialmente um deus que se coloca fora de si mesmo através de uma "criação". Nesse sentido, o deus cristão - talvez já o deus monoteísta - é o deus que se aliena, que se ateiza ou ateologiza. Conforme uma a-teologia enquanto pensamento do corpo, o "deus" se fez “corpo" ao esvaziar-se de si mesmo (kénosis). O “corpo” torna-se o nome do ateu no sentido de "nenhum-deus", o que não significa a autossuficiência imediata do homem e do mundo, mas: nenhuma presença fundante. A essência do monoteísmo é o evanescer da presença que são os deuses das mitologias. O “corpo” da "encarnação" é o lugar ou o evento deste evanescer (Cf. NANCY, 2005, p.125128).

O mistério da Trindade articula o próprio Deus enquanto relação. Resulta daí a configuração de uma ordem do mundo que se legitima a si mesmo e de uma abertura no meio deste mundo, abertura voltada para uma exterioridade que não é outro mundo, mas é o que, no seio do mundo, está em excesso: o "sentido" da relação entre si de todos os seres que fazem ou são esse mundo e que só "têm" esse mundo, independentemente de toda potência exterior. Se o sentido é a própria relação, a exterioridade do mundo está no mundo sem ser do mundo. Em consequência, a encarnação não é a morada provisória do deus na carne, é o "verbo feito carne", ou a própria carne como sentido. É o corpo como imagem visível do invisível, manifestação do que não se manifesta. O corpo é o evento do espírito, isto é, o espírito não se mantém fora do mundo, mas abre-se no meio dele (Cf. NANCY, 2010, p. 74-78). “A encarnação significa que a infinidade divina tenha a sua efetividade na relação dos entes finitos. Logo, que o sentido seja, por essência, finito: interrompido, suspenso sobre a verdade vazia, a fim de evitar o preenchimento sufocante de uma conclusão (NANCY, 2010, p. 108)”. 
Cabe a nós, humanos, mortais, sem deuses e sem natureza, técnicos comprometidos na produção indefinida de um mundo "nosso", fazer sentido - ou, melhor, reconhecer como o sentido pode acontecer. Só é possível na relação que se abre, ao mesmo tempo, entre nós (nós humanos e todos os entes) e em nós, que nos remete simultaneamente uns aos outros e a uma abertura em nós, por onde se manifesta uma remissão infinita: sim, somos seres do sentido, sim estamos encarregados do sentido do mundo, sim a verdade do sentido não é um acabamento, uma plenitude significante, mas é a suspensão pela qual o sentido ao mesmo tempo se interrompe e se relança infinitamente (NANCY, 2010, p. 77-78).

\section{Desconstrução de Deus, do ateísmo e do monoteísmo ${ }^{5}$}

"Um dia, os deuses se retiram. Por iniciativa própria, eles se afastam da sua divindade, isto é, da sua própria presença. Não se ausentam simplesmente: não vão para outro lugar, eles se retiram da sua própria presença: ausentam-se por dentro (NANCY, 2001, p. 7)”. O que faz falta é o corpo dos deuses, só restou o que se pode dizer deles, e o dito tornou-se incorporal, igual ao vazio, ao lugar e ao tempo. $\mathrm{O}$ dito não é mais dado com o corpo divino, ele afasta-se de si, distende-se, torna-se logos. Falta a presença além da figura ou na própria figura. $\mathrm{O}$ discurso caminha até o além do ser, onde fica imerso numa luz excessiva, num ofuscamento que abole toda possível figuração.

A invenção do ateísmo, específica do Ocidente, é correlativa à invenção do teísmo pelos gregos. No theos de Platão, os deuses desaparecem junto com seus mitos e são substituídos pelo princípio. O theos único, desprovido de figura e de nome, representa a invenção do "deus" em geral. A partir daí, ateísmo e teísmo encontram a sua unidade no novo paradigma do princípio. A função lógica substitui a função mítica, que consistia na dupla oposição de uma alteridade radical: deus e homem não estão mais juntos no mundo, e de uma relação do mesmo com o outro: o homem está chamado a encontrar o deus. Na negação do princípio divino, o ateísmo preserva a essência do que ele nega: o princípio representado pela figura de um existente distinto do mundo inteiro dos existentes, do qual ele deteria a causa primeira e o fim último.

${ }^{5}$ Ver especialmente: NANCY, 2005, p. 27-64. Capítulos: "Athéisme et monothéisme" e "Déconstruction du monothéisme".

Horizonte, Belo Horizonte, v. 14, n. 42, p. 518-542, abr./jun. 2016 - ISSN 2175-5841 
O monoteísmo é a confirmação teológica do ateísmo, enquanto redução do divino ao princípio, numa lógica de dependência do mundo. Ou o monoteísmo é, na verdade, o ateísmo. O deus único não é outra coisa senão a repetição do seu ser imutável, sem história nem figura. O nome "Deus" não é o nome de uma figura. Por isso, o "deus" único do monoteísmo não pode ser representado. As imagens de Deus são impossíveis, mesmo quando autorizadas. "Deus” é apenas o substantivo comum - deus, um deus - usado para indicar, mais do que designar, o que escapa de todo nome, o que é inominável (Cf. NANCY, 2015). ${ }^{6}$

A conjunção do ateísmo grego e do monoteísmo judeu na elaboração do cristianismo - configuração maior da onto-a-teologia - reúne apenas duas formações do ateísmo, no qual desaparecem todas as presenças e potências divinas, em proveito de um princípio que só é “divino” no nome, um nome despojado de toda personalidade e até da possibilidade de ser pronunciado. Em termos heideggerianos, Deus nomeia a consistência do ser concebida como princípio, fundação e essência. Representa do modo mais manifesto o ser no princípio do ente: ens summum, verum, bonum. Daí o cristianismo ser apenas um epifenômeno sem especificidade notável em relação à história destinal e epocal do ser. A unicidade converte o ser, de potência ou pessoa presente, em princípio, fundamento ou lei, sempre por definição ausente ou refugiada no fundo do ser. É que o monoteísmo abriga, no mais íntimo de si mesmo, aquém e além de si mesmo, o princípio de um mundo sem Deus.

O "deus" cristão é ateu. "Ateu significa não-posição de "Deus", deposição de todo deus que pode ser posto enquanto tal - isto é, como "ser" ou "sujeito" dotado de tal ou qual propriedade (inclusive a perfeição de todas as propriedades): ora, o "deus" cristão - se é que pode ser assim nomeado - não é posto, nem mesmo auto-posto. Não há nem chão nem lugar para isso: não há nem mundo nem além-mundo, mas uma abertura de sentido que produz o espaçamento do mundo e sua relação consigo mesmo (NANCY, 2010, p. 46-47).

\footnotetext{
6 “'Seja abençoado, ninguém'! Essa fórmula de Paul Celan [...], inspirada na forma dos Salmos de Daví [...], enuncia a mais profunda verdade que declinam as três grandes religiões do tronco abraâmico (e, de outro modo, o budismo), isto é: Deus não é alguém (NANCY, 2015)". É impossível restituir em português a ambivalência do termo Personne, que significa, ao mesmo tempo, "pessoa" e "ninguém".
} 
Nos mitos e ritos, a pluralidade dos deuses corresponde à sua presença poderosa efetiva. O Deus único, ao contrário, renuncia à presença e ao poder. $\mathrm{O}$ Deus de Israel, enquanto dispõe sozinho inteiramente do seu poder, pode subtraílo ou retirar-se dele.7 Ele não espera sacrifícios, mas apenas a fidelidade incondicional à sua aliança, à eleição “ciumenta” do seu povo, de seus fiéis ou do ser humano em geral. Com a figura de Cristo, a renúncia ao poder divino e à sua presença torna-se o próprio ato de Deus. A ausência ou o vazio-de-divindade é a sua verdade mais profunda. Em Jesus, Deus não apenas se ausenta, mas se apaga. Além disso, ele se faz homem, abandona a sua divindade à condição mortal, em vista de revelar a imortalidade na morte. E o homem no qual Deus "desce" e "se esvazia" (a kénosis de Paulo) não é divinizado. Deus permanece apenas como traço, vestígio impalpável, imperceptível. O apagamento de Deus no homem é o sentido do mundo. No fundo, "Deus" era apenas um nome para dizer a relação de todos os entes, para dizer o mundo na força da palavra. Deus apaga-se também na Trindade, pois Deus é relação, é a sua própria relação (Cf. NANCY, 2010, p. 45-46).

O Deus-vivo é o que mantém o ajuntamento de todos os outros elementos da construção. Enquanto vivo, Deus não é nem representado nem representável. Por sua vez, o Filho, "imagem invisível do Deus invisível”, é a sua própria presença, no sentido de um puro anúncio - sem conteúdo - da presença. Deus é o próprio vazio que se abre. O Aberto enquanto tal, o Aberto do anúncio, do projeto, da história e da fé, pelo Deus-vivo, revela-se no coração do cristianismo. Se o tríplice deus do monoteísmo essencialmente fala, é porque a palavra nele se substitui ao exercício e à eficácia do sacrifício. A palavra abre no ser vivo uma alteridade à qual não se trata de ser "religado", mas aberto. Esta alteridade não pode ser nomeada: ela se apresenta como excesso em relação com todo nome. Ela forma a possibilidade infinita de sentido (Cf. NANCY, 2010, p.14-15).

\footnotetext{
7 "Na Cabala, é dito que deus cria o mundo, não fazendo algo mas retirando-se, aspirando-se a si mesmo, esvaziando-se. Cavando-se, deus abre o vazio no qual o mundo pode encontrar o seu lugar. Isso chama-se 'Tsim-Tsum' (NANCY, 2004, p. 55)".
}

Horizonte, Belo Horizonte, v. 14, n. 42, p. 518-542, abr./jun. 2016 - ISSN 2175-5841 
Na desconstrução a partir e em vista do Aberto, perde-se e conquista-se, ao mesmo tempo, o horizonte do sentido como questão e como nome próprio da finitude que se volta para o seu próprio infinito. Pois o Aberto é essencialmente ambíguo: quando se abre exclusivamente sobre si mesmo, infinitamente, o cristianismo torna-se niilismo, morte de Deus, ausência de sentido. Como, ao contrário, um sentido infinito poderia fazer sentido, uma verdade vazia receber o peso da verdade? Como desenhar de novo uma abertura delimitada, uma figura que, contudo, não seja uma captura figurativa do sentido (em outras palavras, que não seja Deus)?

No comentário à Carta de Tiago, Nancy nos oferece um começo de resposta. O Deus gerado pela fé é o Deus da homoiósis, o Deus do qual o homem é imagem. Graças ao homem, o mundo criado carrega o traço ou o vestígio (como dirá Agostinho) da retração da sua origem. Na Carta de Tiago, Deus é, antes de tudo, doador, não de coisas, mas de luz ou claridade. Ele é doador da possibilidade da claridade, na qual - e só nela - pode haver coisas. O doador abandona-se no próprio dom, como diria Jacques Derrida (o outro Tiago!). Deus, ao doar, dá-se da mesma maneira que permanece em si mesmo sem sombra, já que o que ele dá é a própria claridade. O que é dado é o próprio favor do dom, isto é, a retração na graça do doador e do próprio presente (Cf. NANCY, 2005, p. 65-87).

A fé cristã é, assim, fidelidade a uma ausência e certeza dessa fidelidade na ausência de toda segurança. Nesse sentido, o ateu, ao recusar toda segurança consoladora ou redentora, está paradoxalmente mais perto da fé do que o "crente”. O ateísmo, que determina doravante a estrutura ocidental, é, por sua vez, o cristianismo realizado. Este é também um cristianismo desmitologizado e areligioso. Não se interpreta mais a partir de um relato fundador e exemplar, mas manifesta uma simbólica decifrada na condição humana: razão humana, liberdade, dignidade, relação a outrem. 
Assim, a partir do esgotamento da onto-(a)-teologia, o acesso ao Deus vivo só poderá ser conseguido por meio de uma fé que seja desprovida de crenças, de ritos e de instituições, de uma fé sem religião. ${ }^{8}$ Uma fé da razão, a partir da qual toda elaboração teológica será necessariamente negativa. Assim, pode-se dizer que o cristianismo é “a religião da saída da religião” (Marcel Gauchet). O pensamento está diante da tarefa de reassumir a abertura do mundo à própria exterioridade, de abrir a racionalidade à dimensão própria do absoluto, de dar lugar - conforme as palavras de Kant - a uma fé da razão. Kant escreve: “Tive que suprimir o saber para dar lugar à fé" (KANT, 1957, p. 33 (B XXX).9

Infelizmente, ao desabamento do princípio da onto-teologia clássica - com Kant, Nietzsche, Heidegger e outros - não sucedeu uma apreensão nova desse desabamento e do vazio - da abertura - que resulta dele. É que o ateísmo - ou o “absen-teísmo"- continua fechando o horizonte ou, melhor, fazendo horizonte, isto é, limite, impasse e fim do mundo. O ateísmo continua repetindo o niilismo. Como superar a aporia, se toda tentativa de forçar o sentido além dele resultou no horror exterminador? Podemos perceber a dificuldade ao considerar o humanismo, que se apresentou como a verdade, o alcance, a proposição e a operação do ateísmo. Ao reverter a essência do deus na essência do homem, o humanismo produziu apenas uma rotação do princípio sobre si mesmo, deixando intacta a construção onto-(a)teológica. Já percorremos todas as figuras possíveis da "superação infinita do homem pelo homem" (Pascal) e chegamos à conclusão de que a superação assume a forma de uma inexorável dominação dos homens por uma máquina indiferente à sua sorte. Pois, a partir do momento em que o humanismo - que inclui a tecnociência, a democracia, o direito, certo tipo de discurso e argumentação, o universal, o indivíduo e o motivo da superação do homem e no homem por uma transcendência infinita - se mundializa como produção do mercado mundial, ele

\footnotetext{
${ }^{8} \mathrm{O}$ "Deus vivo" é a abertura que subsiste após a desconstrução, não o interlocutor vivo da fé religiosa. É o Deus de uma fé da razão, não sendo nada além dessa abertura em relação ao outro humano, o que significa razão, liberdade, dignidade, abertura à alteridade e à diferença. Cf. infra, p. 14.

${ }^{9}$ A referência, talvez equivocada, a esse pequeno trecho da obra de Kant, é do próprio Nancy. Ela se encontra também em Derrida e em muitos teólogos, geralmente protestantes, do século XX. Não podemos aqui discutir a sua pertinência para o pensamento atual em filosofia da religião e teologia.
}

Horizonte, Belo Horizonte, v. 14, n. 42, p. 518-542, abr./jun. 2016 - ISSN 2175-5841 
desemboca na decomposição do sentido e na desumanidade. Por isso, a saída do capitalismo, componente do humanismo, só poderá ser a saída do niilismo.

A monovalência do valor, na economia capitalista e tecnológica enquanto forma geral do valor e do sentido, se comporta como a transcrição aparentemente não religiosa da monocultura que carregou a concepção monoteísta: a cultura de Roma na sua expansão europeia e moderna. Isso resulta do caráter, ao mesmo tempo absoluto e invisível, incalculável, indeterminável e universal do valor ou do sentido único, que este seja colocado em "Deus" ou no "Homem", ou ainda na tautologia do próprio "Valor". Trata-se, no processo de desconstrução, de discernir o que tornou possível o ajuntamento ou a construção do monoteísmo mundializado e “ateizado”, para pensa-lo como o seu próprio além. Queremos chegar a um ponto, debaixo do cristianismo, do monoteísmo e do Ocidente, que possa nos abrir um futuro para o mundo, que não seria nem cristão, nem anticristão, nem monoteísta nem ateísta ou politeísta, mas além de todas essas categorias.

Trata-se, então, de pensar o limite que encerraria uma existência numa abertura não curvada sobre si mesma, ou de pensar a inscrição de um sentido que nenhuma religião, nenhuma crença, nenhum saber podem saturar ou assegurar, que nenhuma igreja pode pretender recolher e abençoar. Para esse fim, não nos resta nem culto, nem oração, apenas o exercício estrito e severo, sóbrio e, contudo, alegre do que se chama o pensamento.

Enfim, Jean-Luc Nancy remete ao "último deus" de Heidegger, o único deus que ainda poderia nos salvar. É que está sempre para nascer ou para desaparecer um último deus. Esse deus, o último, não porque vem depois de todos os outros, mas porque dissipa e dissolve a própria essência do divino, é um deus que winkt, isto é, que faz um aceno sem significado, um sinal de aproximação, de convite e de partida. "O aceno é dado a partir e em direção do Ereignis, do evento apropriador pelo qual o homem apropriado ao ou pelo ser pode ser desapropriado (enteignet) de uma identidade fechada sobre a sua humanidade e pode se 'propriar', se dirigir, 
se dedicar (zu-eignet) a algo de infinitamente mais alto que ele 'mesmo' (NANCY, 2005, p. 43)”. Para Nancy, no momento está fora de dúvida que um aceno, seja qual for - necessário ou não, isso fica não decidido - se dirige a nós a partir da nossa razão ateia (Cf. NANCY, 2005, p. 155-177). Afinal, o nome divino serve aqui apenas como metáfora para um evento apropriador, metáfora que tanto Heidegger como Nancy tiveram escrúpulo em desconstruir até o fim. O que não deixa de fazer algum sentido.

\section{Implicações éticas}

A partir do que foi dito, ressaltamos que, já no monoteísmo, a fortiori na desconstrução do monoteísmo cristão operada por Nancy, a renúncia ao poder divino e à sua presença (kénosis, Tsim-Tsum) leva à rejeição dos “ídolos” que corporificam o poder divino, à rejeição de toda sacralização opressiva do poder na sociedade e nas religiões. Trata-se da rejeição do controle dogmático e institucional exercido pela religião e da gestão interessada do mundo, que se concretiza na monovalência do valor na economia capitalista e tecnológica. O ateísmo, enquanto cristianismo realizado, leva à valorização da condição humana: razão, liberdade, dignidade, abertura à alteridade e à diferença. A superação da religião permite superar os perigos que ameaçam a mesma condição humana, desativa as formas super-religiosas de exaltação messiânica, mística e profética e reaviva a convivência.

O que resta é a responsabilidade humana de "fazer sentido", de relançar infinitamente o sentido que se interrompe, de deixar o sentido infinitamente aberto, pois a tentativa de forçar o sentido além dele mesmo resulta no horror exterminador. Trata-se de superar o humanismo que substitui o teísmo, humanismo no qual a "superação infinita do homem pelo homem" resulta na dominação da humanidade pela grande máquina tecnológica e econômica. Quando o humanismo se mobiliza como produção do mercado mundial, ele desemboca na 
decomposição do sentido e na desumanidade. Trata-se agora de manter a abertura do sentido contra toda religião, todo saber, toda crença, toda igreja.

Jean-Luc Nancy escreve, num artigo publicado na ocasião do ataque ao semanário "Charlie-Hebdo":

\begin{abstract}
Aquele - Deus, Ninguém - não providencia uma lei determinada, nem um regime social, nem político, nem econômico determinado. Pois se tudo é dado, fixo, inamovível, então o infinito divino é negado. Deus/Ninguém torna-se um fetiche, isto é, um falso deus, ou um ídolo. Este falso deus pode tornar-se instrumento para toda espécie de desejo de poder e dominação. É honrada uma fé que não se deixa usar por interesses de poder ou dominação. O verdadeiro Deus ou a verdade de "deus" nos espera em outro lugar do que no fetichismo, isto é na superstição dos nomes, das figuras, das representações diversas, tais como o dinheiro, as armas, a virilidade, a pureza, a salvação etc. Verdadeiramente em outro lugar, no infinito - o que não está num outro mundo, mas que se abre aqui e agora, cada vez neste mundo onde existimos. O "infinito" não é nada enorme ou inatingível. É simplesmente isso: não parar em nada de determinado, fixado, identificado, nomeado por um pretenso nome próprio (NANCY, 2015).
\end{abstract}

Nesse sentido, trata-se de rejeitar a reivindicação das religiões monoteístas: possuir o nome que pretende nomear o Único. ${ }^{10}$

\title{
4 Reflexões críticas
}

As considerações que se seguem foram pensadas, num primeiro momento, a partir de uma perspectiva teológica. Contudo, nos parecem válidas também na ótica de uma filosofia da religião. A redução do discurso teológico a um pensamento puramente abstrato deve ser objeto de reflexão e crítica racionais nos dois campos de pensamento. Nesse sentido, não hesitamos em recorrer ao pensamento de Paul Tillich, que incorporou o questionamento filosófico à sua teologia.

\footnotetext{
${ }^{10}$ Nós nos limitamos, e de modo resumido, às implicações éticas que decorrem da desconstrução do monoteísmo. Este, por sua vez, já tinha operado a desconstrução dos "ídolos" que corporificam o poder divino. Não podemos esquecer que, antes de ser filosófica, a desconstrução já é própria do cristianismo.
}

Horizonte, Belo Horizonte, v. 14, n. 42, p. 518-542, abr./jun. 2016 - ISSN 2175-5841 
Em primeiro lugar, falar nos laços indestrutíveis que ligam o cristianismo e o Ocidente é tocar num tema já muito discutido na teologia e na filosofia da religião, em particular desde Hegel e o romantismo. Pois, querer começar a história da Europa com o Iluminismo é negar as evidências. Antes disso, há milênios de religião, de teologia e de filosofia. Podemos incluir o judaísmo e o islã, ao longo da história toda, embora o islã tenha, em grande parte, desistido do pensamento crítico. A própria Filosofia das Luzes não se sustenta sem o substrato cristão. A auto-interpretação do Ocidente - inclusive da tradição anterior ao cristianismo não pode prescindir da ideia de encarnação nem da figura de Jesus, o Messias, sujeita a permanentes refundições e recomposições em todos os setores, religiosos e não religiosos, sem perder a identidade e a função de mediador entre a transcendência e a imanência. Ela não pode prescindir da dialética trinitária, nem da ideia de Deus, nem da noção de fé. O mérito de Jean-Luc Nancy é tentar repensar a questão sobre bases não religiosas, por assim dizer, ateias, o que Dietrich Bonhoeffer anunciou, mas não levou às últimas consequências, mantendose no âmbito da fé cristã.

Em segundo lugar, Jean-Luc Nancy frisa com razão que o cristianismo não nasceu com Jesus nem com os apóstolos, mas ao longo de um processo que levou dois ou três séculos. É o que afirma, entre outros, o teólogo reformado Pierre Gisel, fazendo aqui obra de historiador: "O cristianismo é o produto de uma grande recomposição religiosa, conforme uma disposição amplamente antecipada antes da cristalização que será justamente chamada de cristã e configurada como uma possibilidade entre outras (GISEL, 1999, p. 40).” Há, no ponto de partida, uma irredutível pluralidade, sobre o pano de fundo da mutação do judaísmo num contexto "gnóstico", de uma aculturação no contexto da Antiguidade chamada tardia e de uma referência a uma figura chamada Jesus.

Conforme a própria lógica do cristianismo, Jesus não é o fundador do movimento. Não é apresentado desse modo nem funciona assim, como seria o caso de um iniciado trazendo uma revelação especial de Deus. 
Sendo o cristianismo uma religião do livro, o que foi canonizado são textos escritos por crentes, retomando os conteúdos de um modo próprio, e não as palavras de Jesus. Além disso, o livro é duplo: Antigo e Novo Testamento, em constante intertextualidade (GISEL, 1999, p. 217).

O cristianismo propriamente dito cristaliza-se, entre o segundo e o quarto século aproximadamente, no contexto da Antiguidade tardia, da qual ele propõe uma síntese própria. Só encontra suas expressões ditas "clássicas" no século IV.

Tampouco podemos negar que a modernidade seja a continuidade do cristianismo. É o nosso terceiro ponto. Basta mencionar o tema da secularização, tratado antes de tudo pelas ciências sociais, que só faz sentido em ambiente cristão (ou, pelo menos, monoteísta). De fato, a maioria dos historiadores da cultura ocidental reconhece na secularização um dos fenômenos marcantes da modernidade, consequência direta do processo de emancipação do sujeito individual racional e de suas implicações políticas e científicas. Hoje se vê melhor que a secularização não significa o fim da religião. Trata-se, antes, da "autonomização" do domínio "secular" ou profano ou da emancipação progressiva da tutela religiosa - cristã, no contexto ocidental - alcançada em todos os setores da cultura: política, economia, ciência, moral, direito, educação, arte etc. A secularização libera a sociedade da tutela das religiões ou, mais exatamente, dos seus órgãos de autoridade, as igrejas (Cf. ISAMBERT, 1998).

Conforme Paul Tillich, as duas grandes correntes religiosas do Ocidente: o catolicismo e o protestantismo, concordam na compreensão da modernidade como secularização, reconhecendo seus aspectos positivos e negativos. Para ele - como para Weber e Troeltsch, entre outros - o protestantismo é a religião da modernidade, a religião do secular e da autonomia da cultura moderna. Seria ele também "a religião da saída da religião"? Parece ser o caso de uma França laicizada. É menos evidente na América latina e no Brasil, onde a maioria daqueles que se dizem "sem religião" quer simplesmente significar que não aderem a nenhuma religião estabelecida. É verdade, contudo, que a rejeição da instituição pode ser entendida como elemento da secularização. Por outro lado, não se pode 
afirmar com tanta certeza que o cristianismo tenha "deixado de ser estrutura organizadora de uma experiência coletiva”, por exemplo, no pentecostalismo e nos movimentos populares.

Em quarto lugar, pensamos que a atenção ao absoluto sem nome não pode prescindir do elemento simbólico. Para Tillich, a fé precisa dos símbolos religiosos, que possuem “o poder da eterna transparência do sentido eterno" (TILLICH, 1995, p. 361). Os símbolos apontam para uma realidade que só eles podem evocar, e tornam presente essa realidade última pelo poder de participação que transmitem. A preocupação suprema do ser humano exige uma expressão simbólica. Pois o verdadeiro absoluto transcende infinitamente o domínio da realidade finita. Deus transcende o próprio nome. Por isso, a fé não tem expressão adequada fora da linguagem simbólica. Deus é o símbolo do que nos diz respeito de maneira absoluta. Os símbolos suscitam o pensar (Ricoeur) e povoam o "mundo da vida". Isso vale também para os símbolos dogmáticos ou conceituais, como a Trindade, que Nancy reduz à sua dimensão onto-teo-lógica. Além disso, todo símbolo é ambíguo como a experiência do sagrado que o fez nascer. O melhor símbolo é aquele que expressa, não apenas o absoluto, mas também a sua própria incapacidade de alcançar o absoluto (CHAPEY, 1968, p. 15). A desvalorização da experiência concreta da religião e da fé vividas leva Jean-Luc Nancy a desprezar a dimensão mítica e simbólica da religião. Mesmo filosófica, a fé não pode dispensar as crenças, as imagens e as representações. Tampouco pode prescindir da tradição das testemunhas e das narrativas. Por que o sentido no seu excesso deve necessariamente ser vazio? Por que o Evangelho - mesmo se for o Evangelho da razão - deve ser anúncio sem conteúdo?11

Em quinto lugar, a teologia percebeu há muito tempo que a auto-superação faz parte da "essência" do cristianismo. Há uma capacidade inata de "reforma" que

\footnotetext{
${ }^{11}$ Essa crítica, formulada a partir da perspectiva teológico-filosófica de Paul Tillich, pode ser aplicada também a uma fé da razão que, do Deus presente, guarda apenas a abertura radical do mundo dentro dele mesmo. É essa abertura que é caracterizada por Nancy como o Absoluto, que fica definitivamente fechado a qualquer tipo de figuração. Defendemos a posição de que a "desmitologização" do cristianismo não pode ser total, mesmo na perspectiva de uma filosofia desconstrutiva da religião. Pois a simbolização imagética é uma necessidade do pensamento humano.
}

Horizonte, Belo Horizonte, v. 14, n. 42, p. 518-542, abr./jun. 2016 - ISSN 2175-5841 
procura sempre os seus fundamentos nas origens históricas: Jesus, as primeiras comunidades, o Novo Testamento, onde estaria conservado o "Evangelho eterno", submetido a um processo de releitura hermenêutica por todos os fundadores de movimentos, desde os monges do deserto até o pentecostalismo, passando pelos múltiplos messianismos e espiritualismos, sincréticos ou não. A separação radical entre saber e fé, preconizada por Kant e mencionada várias vezes por Jean-Luc Nancy, é uma das consequências da valorização cristã - sobretudo, protestante do secular. O final do processo bem pode ser o ateísmo, segundo o leme famoso de Ernst Bloch: “o cristão é o verdadeiro ateu; o ateu é o verdadeiro cristão”.

Em sexto e último lugar, voltaremos à questão da desconstrução do teísmo e do monoteísmo. Acompanhamos novamente o teólogo reformado Pierre Gisel. Para ele, um momento de "teologia negativa” deve sempre ser convocado, momento de crítica, até de desconstrução e de superação das realidades positivas da fé - os ritos, os símbolos, a Escritura, a confissão - em benefício da verdade do que se diz nelas. Gisel faz referência a Platão, Dionísio o Areopagita, Eckhart, mas também a Tomás de Aquino (GISEL, 2002, p. 368). Vejamos, por exemplo, Meister Eckhart, quando identifica a divindade como o uno:

Uno significa aquilo ao qual não se pode acrescentar nada... O Uno é a negação da negação. Todas as criaturas carregam uma negação em si; uma nega a outra. Um anjo tem em si a negação pelo fato de não poder ser outro anjo. Deus, porém, é a negação da negação. Ele é um e nega todos os outros, pois nada existe fora de Deus. Todas as criaturas são em Deus e são sua própria divindade e isto significa a plenitude (ECKHART, 1958, p. $514)$.

Ou ainda: "O homem não deve se contentar com um Deus pensado, pois quando o pensamento passa, passa também Deus. Deve-se, antes, possuir um Deus essencial que de muito ultrapassa os pensamentos dos homens e de todas as criaturas. Este Deus não passa (ECKHART, 1963, p. 510)”. “O Uno se encontra livre de toda espécie de multiplicidade e diferença; (Uno este) em que também Deus-Pai-Filho-e-Espírito-Santo perde-se e despoja-se de todas as diferenças e 
propriedades, e é, e são, Um só (BOFF, 1983, p. 73)”. Na mesma linha, encontramos, em Jean-Luc Nancy, a ideia de Deus enquanto o Aberto enquanto tal.

A “superação do teísmo" na modernidade foi objeto de reflexão teológica na primeira metade do século XX, muitas vezes em diálogo com Heidegger. Podemos mencionar Rudolf Bultmann (um Deus des-mitologizado), Friedrich Gogarten (Teologia da secularização), Dietrich Bonhoeffer (cristianismo a-religioso), Schubert Ogden e Paul Tillich (Deus acima de Deus e Deus transpessoal). Esses pensadores influenciaram o movimento da “Teologia da morte de Deus", com Altizer, Vahanian, Hamilton, Van Buren. Vejamos, por exemplo, Paul Tillich: "Não quero pensar Deus num sentido cristão, como uma forma separada. Nesse ponto, não posso concordar com as tendências teístas dentro do cristianismo. Pelo contrário, concordo com a via budista, com as tendências místicas gerais (TILLICH, 2002, p. 150)". De modo semelhante: “Afirmar a existência de Deus ou negá-la é ateísmo. Deus é o ser-em-si, não um ser (TILLICH, 1984, p. 200)”. Em Tillich, o “Deus acima de Deus” é o Deus além do Deus teísta. É a superação do teísmo, pois o Ser-em-si supera paradoxalmente os nomes e predicados pelos quais a razão humana o designa. Além de paradoxal, este Deus além do Deus do teísmo é a presença de uma ausência em todo encontro divino-humano. Este Deus só pode ser evocado quando o ser humano supera o desespero existencial no salto da fé. E este salto só é possível porque a fé é o estado daquele que é possuído por aquilo que é a sua preocupação última. Assim, a perda de sentido é conquistada na medida em que o Deus todo-poderoso, o Deus além de todas as coisas, o fundamento e abismo do ser, torna-se a preocupação última do ser humano.

O Deus do teísmo teológico é um ser ao lado dos outros e, enquanto tal, é uma parte do conjunto da realidade. (Desse modo) está submetido à estrutura da totalidade. [...] Assim, é considerado como um si que possui um mundo, como um "eu” em relação com um "tu", como uma causa separada do seu efeito, como dispondo de um espaço infinito e de um tempo sem fim. Logo, ele é um ser, não o próprio ser. Como tal, ele é subordinado à estrutura sujeito-objeto da realidade, ele 
é um objeto para nós que somos sujeitos. Ao mesmo tempo, somos objetos para ele enquanto ele é sujeito. É por isso que precisamos superar o teísmo teológico. Pois um Deus entendido como sujeito faz de mim um objeto e nada mais. Despoja-me da minha subjetividade porque é todo-poderoso e onisciente. É o Deus do qual Nietzsche dizia que precisava mata-lo, pois ninguém pode tolerar ser transformado pura e simplesmente em objeto de conhecimento absoluto e de dominação absoluta. É aí que se encontra a raiz mais profunda do ateísmo. Esse ateísmo se justifica como reação contra o teísmo teológico e suas consequências inquietantes. O personalismo na relação com Deus deve ser compensado por uma presença transpessoal do divino. Pois todo mundo sabe que um deus não deve ser nem demasiadamente nem insuficientemente personificado: no primeiro caso, a sua majestade se dissolve na anedota; no segundo, não se sabe mais como prestar um culto a um deus sem paixões, sem emoções (TILLICH, 1967, p. 180-182).

Contudo, Jean-Luc Nancy retrucaria que Deus não é inominável no sentido metafísico do ser que transcende todos os nomes, inclusive o nome do próprio ser, segundo a tradição consistente que já pertence à onto-teo-logia (como em Dionísio, Eckhart ou Ruysbroek). Pois o caráter inominável do deus resulta de uma falta de nome, não de um excesso em relação aos nomes e à linguagem. É o nome próprio de Deus que está em falta. O que há é uma impotência dos nomes em geral em nomear Deus. ${ }^{12}$ Reciprocamente, o inominável não é nem necessariamente nem exclusivamente divino (NANCY, 1997, p. 10). Essa falta de nome revela a própria divindade como suspensa. É aqui que Nancy se distancia radicalmente de toda teologia cristã, mesmo se uma (a)teologia filosófica não teísta e não religiosa pode percorrer, junto com ele, uma boa parte do caminho. Assim, a confluência entre a abordagem filosófica e a perspectiva teológica só se realiza parcialmente. 12 "O destino para nós de todos os nomes divinos - ou do divino em todos os nomes: eles não designam mais deuses, isto é: não
podemos mais chamar os deuses com seus nomes: Indra, Zeus, Wotan, Javé, Jesus" (NANCY, 1997, p. 11).

Horizonte, Belo Horizonte, v. 14, n. 42, p. 518-542, abr./jun. 2016 - ISSN 2175-5841 


\section{Considerações finais}

Ao concluir este ensaio, seria fastidioso retomar mais uma vez a exposição anterior, de modo resumido. Gostaríamos, a título de provocação pessoal em vista do aprofundamento da reflexão, de chamar a atenção para uma semelhança estrutural entre a desconstrução e o método do tratado kantiano sobre a religião, ao qual Nancy recorre constantemente. Tratava-se de abstrair da religião o que a simples razão pode reconhecer como procedendo dela mesma. Como Nancy, Kant já procurava reabrir a clausura da metafísica, dando lugar a uma fé da razão cavada no coração do cristianismo. Ele também encontrou um exterior do mundo em plena imanência mundana, com a luta do imperativo moral contra o mal radical. Desconstruindo e superando as realidades positivas da fé: os ritos, os símbolos, a Escritura, a confissão, Kant estava à procura de uma abertura de sentido nos confins da religião cristã. Ele também queria reabrir ao sentido - à luz da razão doutrinas essenciais do cristianismo como a cristologia, a Trindade, a Graça, dando um voto de confiança ao seu caráter racional. Segundo Paul Ricoeur, o pensamento legítimo do Incondicionado torna possível a ilusão transcendental, cuja região coincide exatamente com o domínio da esperança de que fala a pergunta kantiana: “O que me é permitido esperar”? Ora, o tema da esperança possui força suficiente para causar rachaduras nos sistemas e iniciar uma reorganização do sentido. Para Jean-Luc Nancy, a esperança designa a tensão interna à pulsão que caracteriza a virtude: não a esperança de que algo - resultado, conclusão - se produza, mas a tensão preservada na confiança de que sempre algo ou alguém está vindo. Resta nós a esperança pela volta dos deuses, pois não se pode cantar ou dançar frente ao vazio-de-deus. Contudo, precisaremos sempre desconfiar de um deus que abençoa as armas e os poderes opressores. 


\section{REFERÊNCIAS}

BOFF, L. Introdução. In: ECKHART (Mestre). A mística de ser e não ter. Petrópolis: Vozes, 1983.

CAHEN, D. Jean-Luc Nancy. In: Encyclopaedia Universalis. DVD-Rom 2012. Paris: Universalis, 2012.

CHAPEY, F. Introduction. In: TILLICH, P. Dynamique de la foi. Paris : Casterman, 1968.

ECKHART (Meister). Die deutsche Werke I. Stuttgart: Kohlhammer, 1958.

ECKHART (Meister). Die deutsche Werke V. Stuttgart: Kohlhammer, 1963.

ECKHART (Mestre). A mística de ser e de não ter. Coord. BOFF, L. Petrópolis : Vozes, 1983.

GAUCHET, Marcel. Le désenchantement du monde. Paris: Gallimard, 1985.

GISEL, P. La théologie face aux sciences religieuses. Genève : Labor et Fides, 1999.

GISEL, P. Penser la religion aujourd'hui. Données et tâches à assumer à partir de la tradition théologique. In : GISEL, P. \& TETAZ, J-M (Eds.). Théories de la religion. Genève : Labor et Fides, 2002.

ISAMBERT, F-A. Sécularisation. In : Encyclopaedia Universalis, CD-Rom Universalis $n^{0} 4$. Paris: Universalis, 1998.

KANT, I. Kritik der reinen Vernunft. In: KANT, I. Werke in sechs Bänden (WEISCHEDEL, W., ed.). Frankfurt/Darmstadt: Wissenschaftliche Buchgesellschaft, v.2, p. 1-307, 1957.

NANCY, J-L. L'adoration (Déconstruction du christianisme II). Paris:

Galilée, 2010.

NANCY, J-L. Au ciel et sur la terre. Petite conférence sur «Dieu ». Paris: Bayard, 2004.

NANCY, J-L. La déclosion (Déconstruction du christianisme I). Paris: Galilée, 2005 .

NANCY, J-L. Des lieux divins, suivi de Calcul du poète. 2. ed. Mauvezin (França): T.E.R., 1997. 
NANCY, J-L. Dieu, Charlie, Personne. Mediapart. Disponível em: <http://blogs.mediapart.fr/edition/les-invites-de-mediapart/article/270115/dieucharlie-personne>. Acesso em: 07/05/2015.

NANCY, J-L. Un jour les dieux se retirent. Bordeaux : William Blake \& Co, 2001.

TILLICH, P. Le courage d'être. Paris : Casterman, 1967.

TILLICH, P. Do nome sagrado. Entrevista com os professores Atsushi Nobukuni e Rijin Yasuda. Trad. R. M. Gonçalves. Correlatio. São Bernardo do Campo, SP, v.1, n.2, p. 133-160, 2002.

TILLICH, P. Teologia Sistemática. 5. ed. São Leopoldo, RS: Sinodal, 2005.

TILLICH, P. Substance catholique, principe protestant et décision socialiste. In: TILLICH, $P$. Substance catholique et príncipe protestant. Paris/Genève/Québec : Cerf/Labor et Fides/Laval, p. 347-362, 1995. 